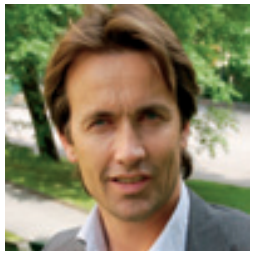

\title{
Opplysningsplikt til barnevernstjenesten
}

\begin{abstract}
Helsepersonell kan være døråpneren
til et bedre liv for barn som lever med belastninger. Derfor ble det nylig

foreslått endringer i barnevernsloven, endringer som også vil få konsekvenser for leger og annet helsepersonell.
\end{abstract}

Alt helsepersonell har opplysningsplikt til barnevernet. Det innebærer at dersom det er grunn til å tro at et barn blir mishandlet $i$ hjemmet eller det foreligger andre former for alvorlig omsorgssvikt, skal leger og annet helsepersonell uten hinder av taushetsplikten gi opplysninger til barnevernstjenesten om dette. Det samme gjelder når et barn har vist vedvarende og alvorlige atferdsvansker.

Opplysningsplikten er sterk. Som offentlig instans har leger og helsepersonell en «meldeplikt» som faktisk innebærer at det er straffbart å unnlate å melde fra til barnevernet dersom det er grunn til å tro at det foreligger mishandling eller alvorlig omsorgssvikt. At en skal ha «grunn til å tro» for å kunne si ifra, betyr ikke at en må ha sikker viten om at det forekommer mishandling eller alvorlig omsorgssvikt. Det er barnevernstjenesten som skal undersøke dette nærmere.

Som barneombud er jeg svært opptatt av at alle yrkesgrupper skal kjenne til denne meldeplikten og bruke den hver eneste gang det er nødvendig. Leger eller annet helsepersonell er kanskje de første til å oppdage at et barn har et vanskelig liv og trenger hjelp. Bekymringer oppstår av og til i direkte møter med barn, men det er også grunn til å være på vakt når foreldre som er pasienter har belastninger som kan påvirke omsorgsevnen. Mange leger har pasienter som strever med rusmisbruk, alvorlig somatisk sykdom eller psykiske lidelser. Dette er forhold som gjør noe med foreldrekompetansen. Derfor skal en lege alltid undersøke hvordan det står til med barna hjemme hvis det er grunn til å tro at en forelder i kortere eller lengre tid har nedsatt omsorgsevne på grunn av sin helsetilstand.

Mange tenker at barnevernet allerede er koblet inn når de møter et barn som blir utsatt for omsorgssvikt. Det kan naturligvis være tilfellet, men det er lite å tape på å undersøke saken nærmere. Leger som har sendt en bekymringsmelding til barnevernet ved ett tilfelle, bør også undersøke om det kan være behov for å ta kontakt med barnevernstjenesten på nytt hvis bekymringen for samme barn vedvarer. Mange saker, trolig altfor mange, i barnevernstjenesten henlegges, både før og etter undersøkelse. De fleste saker der tiltak settes inn, avsluttes også etter en tid. Derfor skal en ikke slå seg til ro med at melding allerede er gitt. Siden forrige gang en meldte en bekymring kan saken være avsluttet eller henlagt av barnevernstjenesten.

Det foreslås nå at offentlige instanser alltid skal få tilbakemelding fra barnevernet dersom de har meldt bekymring for et barn. Dette er bra. Hvis forslaget går igjennom, vil det at barnevernet gir relevant og god informasjon om sitt arbeid med saken gjøre at samarbeidet rundt barnet fungerer bedre.

For leger og annet helsepersonell kan det være en utfordring å vite når opplysningsplikten skal oppheve taushetsplikten. Det kan være vanskelig for noen å tolke loven, og mitt kontor får flere henvendelser fra instanser som synes det er vanskelig å vite når man skal «melde» bekymring om et barn. Det kan se ut som om terskelen for å gi opplysninger til barnevernet er for høy, noe som kan tyde på at vilkårene i bestemmelsen er for strenge. Jeg har derfor i mitt høringssvar til de nye endringene $\mathrm{i}$ barnevernsloven bedt departementet om å vurdere å gjøre endringer slik at terskelen senkes.

Redselen for å bidra til en angiverkultur er trolig med på å høyne terskelen for å si ifra til barnevernet om de bekymringer en har om et barn. Manglende tro på det lokale hjelpesystemet er et annet element som gjør at en nøler med å ta kontakt med hjelpesystemet. Barnevernstjenesten har et dårlig omdømme mange steder, og ofte er dette omdømmet både urettferdig og skadelig for arbeidet som gjøres for barna. Det er barnevernstjenestens hovedansvar å bygge sitt eget renommé utad, slik at både private $\mathrm{og}$ profesjonelle føler at de kan ta kontakt når de har behov. Samtidig bør dere som leser dette være godt orientert og kjent med det lokale barnevernet, slik at dere kan videreformidle til pasientene et riktig bilde av den tjenesten som skal hjelpe barn og familier i større og mindre familievanskeligheter.

Alle vi som jobber hos Barneombudet, snakker ofte med barn og unge som har fått bistand fra barnevernet. Felles for svært mange av disse er at de kan fortelle at barnevernet fikk vite om dem for sent $o g$ at hjelpen burde ha kommet mye tidligere. Underveis, når problemene har tårnet seg opp, er det mange rundt barna som har sett og sett bort uten å ta de nødvendige steg for at barn og familier skal få hjelp. Dette kan være lærere, helsepersonell og personer i det private nettverket. Mange har slike fortellinger om alle de voksne som ikke ville se.

Dere som henviser barn og ungdommer videre, må ta initiativ overfor de andre hjelpende instansene dere kobler inn, slik at dere kan være med i overlappingsmøter og bidra med kunnskap og kompetanse underveis. Dere er en viktig del av barnas sikkerhetsnett, og dette fungerer best om de ulike maskene i nettet faktisk henger sammen.

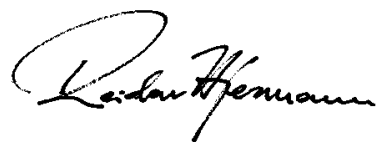

\section{I neste nummer:}

Lindrende sedering

Granulocyttransfusjon

Hestekastanje
Fertilitet

Legers jobbtilfredshet

Arbeidsrelatert sykdom 